\title{
PCR-SSCP AND SEQUENCING OF CXCR1 (IL8RA) GENE IN INDIAN WATER BUFFALO
}

\author{
Manpreet Kaur ${ }^{1}$, Ramneek ${ }^{2}$, C.S. Mukhopadhyay ${ }^{2}$ and Jaspreet Singh Arora ${ }^{2}$ \\ ${ }^{1}$ PAU regional research station, Faridkot, Punjab. India \\ ${ }^{2}$ School of Animal Biotechnology, GADVASU, Ludhiana, Punjab \\ Corresponding author's email: kaurman12@gmail.com
}

\begin{abstract}
Genetic markers associated with inflammatory responses could help in selecting the animals susceptible/tolerant to mastitis. The selective breeding assisted by these markers could help to reduce the huge economic losses that are posed by various forms of mastitis. One possible marker is CXCR1, a chemokine receptor that is required for neutrophil migration to infection site. Therefore the present study was planned to identify genetic polymorphism (if any) in CXCR1 gene and associate it with subclinical mastitis in Riverine buffalo of Northern India. For this, two hundred healthy lactating water buffalo were randomly chosen from the herds maintained by various farmers in Kapurthala District of Punjab, India. Blood and milk samples of selected buffaloes were collected. Screening of the animals for sub clinical mastitis was done by SCC and CMT assays of milk samples. Genomic DNA was isolated from blood samples by phenol chloroform method. The DNA of good quality was used for further analysis. PCR-SSCP was used to explore the polymorphism in $311 \mathrm{bp}$ fragment of partial exon2 of CXCR1 gene. The 311 bp fragment of CXCR1 gene was found to be monomorphic in all the DNA samples screened of Indian water buffalo.
\end{abstract}

Keywords: CXCR1; PCR-SSCP; Indian water buffalo; Sequencing.

\section{Introduction}

Although mastitis has been recognized as one of the most expensive diseases affecting dairy animal's worldwide but subclinical form of the mastitis is very serious illness as it does not lead to any change in phenotypic expression but responsible for reduced milk quantity as well as quality (as undesirable changes in the milk's composition). Mastitis poses high losses to Indian economy as overall losses due to mastitis are estimated to be Rs. 7165.51 crores (Bansal and Gupta, 2009). Subclinical mastitis poses more loss to economic values than the clinical form does.

Other than the environment factor or management factor, genetics of the animal can also be a key player in controlling the disease as under the same environment and management some animals suffer from the disease while other remains healthy. As mastitis resistance is genetically determined, selective breeding can be used to improve udder health. Many candidate genes are being studied for mastitis tolerance/susceptibility in order to find out the molecular markers associated with the disease incidence. Majority of the candidate genes have role in the host immune system. Genes associated with immune responses of mammary gland are possible genetic markers because of their importance in mastitis. Besides, genes associated with neutrophil function are potential genetic markers for mastitis, as neutrophil relocation from blood to the sites of infection is essential for resolution of most mastitis pathogens (Paape et al., 2000). The ability of neutrophils to migrate into infected tissues is dependent upon recognition of inflammatory mediators by neutrophil cytokines, chemokines and complementary receptors (Burvenich et al., 1994). IL-8 is one such important chemo attractant and activator of neutrophils required for the migration of these cells at sites of inflammation (Huber, 1991). It interacts with neutrophils through specific chemokine receptors (CXCRI and $C X C R 2$ ) (Fig. 1) present on the surfaces of neutrophils (Ahuja et al., 1996; Lahaussa et al., 2008). Recognitionof chemokines by CXCR1 and CXCR2 induces neutrophil activation, chemotaxis and eventually phagocytosis of pathogen (Peveri et al., 1988). CXCRl a class-A, rhodopsin-like G-protein-coupled receptor (GPCR), located on chromosome 2 and act as receptor for chemoattractants and neutrophils activating cytokines which are responsible for cellular signal transduction (Katritch et al., 2012).The activity of CXCR1is strongly associated with the inflammatory response to Gram-negative bacteria infections, and consequently is a key player activating the innate immune response ( Rainard and Riollet, 2006).The CXCR1(Located on Chr 2 in cattle and humans; Chr 1 in mice) gene has been mapped approximately $90.3 \mathrm{cM}$ from 
the centromere of bovine chromosome (BTA) 2 and these loci are approximately $1.3 \mathrm{cM}$ from the natural resistanceassociated macrophage protein (NRAMP)-1, (a polymorphic gene related to immune function), indicating that this region of BTA 2 may be associated with immune function and disease resistance (Grosse et al., 1999).Being a key player in transmitting the signal from IL-8 to downstream, the receptors of IL- 8 are the important candidate genes for mastitis tolerance/susceptibility study in the herd. So, CXCR1gene was explored for possible SNPs associated with mastitis resistance/susceptibility. In the present work, PCR-SSCP was used to identify SNPs in CXCR1 receptor gene of Indian water buffalo and possible association with subclinical mastitis.

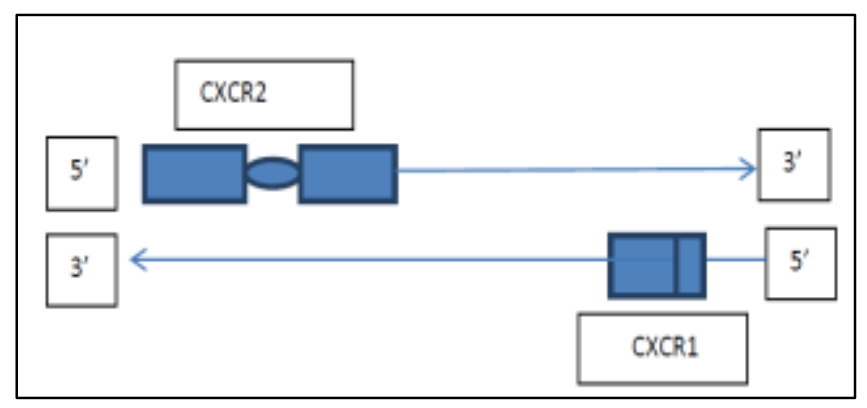

Fig. 1: Schematic representation of relative genomic locations and structure of bovine CXCR1 (GenBank Gene ID: 100125580) and CXCR2 (GenBank Gene ID: 782719) according to GenBank. Blue rectangular boxes represents exons, while circle represents intron.

\section{Material and Methods}

\section{Selection of experimental buffaloes and screening of animals for sub clinical mastitis}

Two hundred she-buffaloes (140 of Murrah breed and 60 of Nili Ravi) were randomly chosen from the herds maintained by various farmers in Kapurthala District of Punjab, India, to determine status of sub-clinical mastitis.Screening of the animal for the disease occurrence was done by CMT (California Mastitis Test) (Fig. 2) and somatic cell count as per the standard protocol .CMT test was conducted and interpreted as per standard method described by Pandit and Mehta (1969). The somatic cell count in milk was analyzed by Somascope Cell Counter (Delta, The Netherlands) (Fig. 3).After screening for sub clinical mastitis, the buffaloes were categorized into two groups i.e. normal (146) and subclinical (54).10 $\mathrm{ml}$ of blood sample from these animals was collected using $16 \mathrm{G}$ needle from the jugular vein in 15 $\mathrm{ml}$ sterile tube (with anticoagulant $0.5 \mathrm{ml}$ of $0.5 \mathrm{M}$ EDTA). The collected blood samples were mixed gently with anticoagulant and then transported to the laboratory in a thermocol box containing ice and cool packs. The blood samples were kept at $-20^{\circ} \mathrm{C}$ until the isolation of genomic DNA.

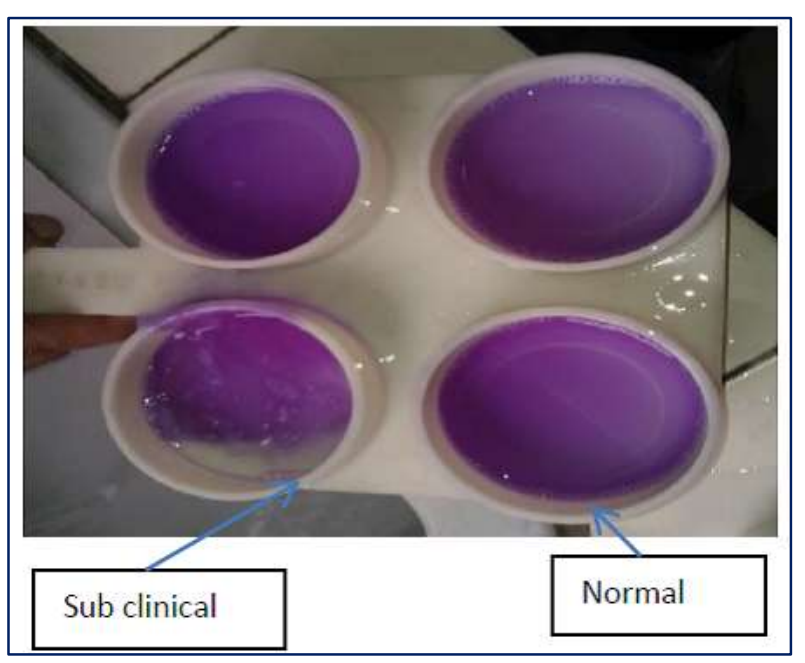

Fig. 2: CMT analysis showing normal and subclinical samples

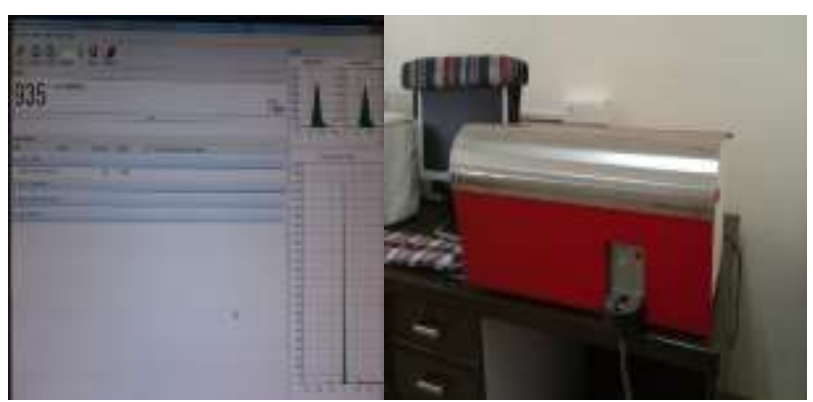

Fig. 3: SCC of subclinical mastitis sample using SomaScope cell counter (Delta, The Netherlands).

\section{DNA extraction and Polymerase Chain Reaction}

Genomic DNA was isolated from the frozen blood samples following the phenol-chloroform extraction method given by Sambrook and Russell (2012). The purity and concentration of genomic DNA was assessed by nano drop spectrophotometer (Thermo Scientific).The samples with purity $(\sim 1.8)$ were considered as pure DNA and the same were checked qualitatively on $0.8 \%$ agarose gel .The intact DNA were stored at $-20^{\circ} \mathrm{C}$ for further analysis.

A small $311 \mathrm{bp}$ fragment of CXCR1 gene comprising partial exon-2 region of CXCR1 receptor gene was amplified using a set of forward 5'-CTTCCGTGAGGCCTATCAAC; reverse AGG TCT CAG CAA TCA CAT GG primers, published for cattle (Zhang et al. 2012).The $25 \mu$ l of PCR reaction mixture was prepared using 20 pmoles of each primer, $200 \mu \mathrm{M}$ of each dNTPs, $2.5 \mathrm{mM} \mathrm{MgCl}_{2}, 2.5 \mathrm{ul}$ of 10 X PCR assay buffer, 80-100 ng DNA template and $1.5 \mathrm{U}$ Taq DNA Polymerase (Invitrogen). The amplification was carried out using a pre-programmed thermal cycler (Eppendorf, Germany)with the following conditions: Initial denaturation of $5 \mathrm{~min}$ at $94^{\circ} \mathrm{C}$, followed by 30 cycles of denaturation at $94^{\circ} \mathrm{C}$ for $1 \mathrm{~min}$, annealing at $53^{\circ} \mathrm{C}$ for $30 \mathrm{sec}$ and extension at $72^{\circ} \mathrm{C}$ for $30 \mathrm{sec}$ and finally the final extension of $5 \mathrm{~min}$ at $72^{\circ} \mathrm{C}$. The PCR products were analyzed by running on $2.5 \%$ agarose gel in $0.5 \mathrm{X}$ TBE buffer (Fig. 4). Ethidium bromide was included in the 
molten agarose $(@ 0.5 \mu \mathrm{g} / \mathrm{ml})$. The run was performed at constant voltage $(100 \mathrm{~V}$ for $2 \mathrm{hr})$. Along with the test samples GeneRuler ${ }^{\mathrm{TM}} 1 \mathrm{~kb}$ plus DNA ladder (Fermentas, USA) and non-template control was also run in one lane. Agarose gels were visualized and photographed under Chemidoc $\mathrm{XRS}^{\mathrm{TM}}$ Gel documentation system (Biorad, USA).

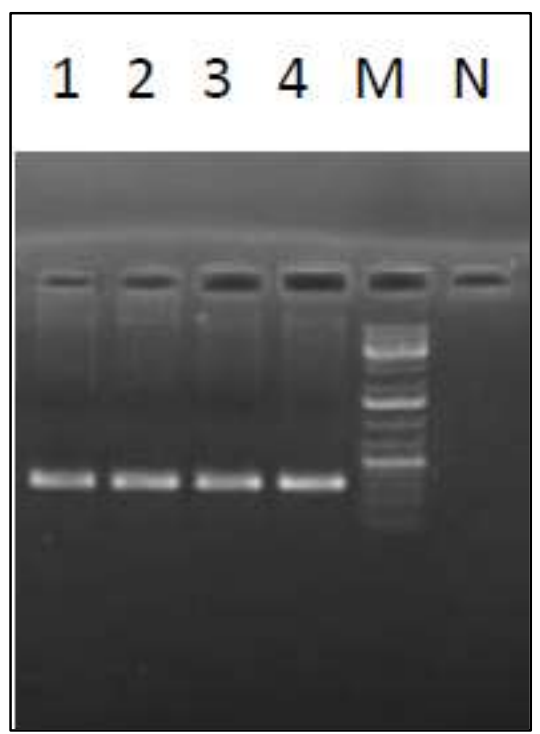

Fig. 4: PCR product of $311 \mathrm{bp}$ fragment of CXCR1 gene. Lane 1-4: Amplification of 311 bp fragment. Lane M: $1 \mathrm{~Kb}$ plus DNA ladder along with non-template control

\section{Single Strand Conformation Polymorphism Analysis}

Single Nucleotide Polymorphisms (SNPs) were screened in this fragment using SSCP technique (Orita et al.1989). The PCR products were resolved on various percentages as well as $\mathrm{A}: \mathrm{B}$ ratios of the gel for optimization,but best results were obtained on $12 \%$ polyacrylamide gel.50 $\mathrm{ml}$ of PAGE solution was prepared by adding $15 \mathrm{ml}$ of Acrylamide: Bisacrylamide (37.5: 1), Autoclaved Distilled water, $5 \mathrm{ml}$ of 5 $\mathrm{X}$ TBE, $10 \%$ Ammonium persulfate $(700 \mu \mathrm{l})$ and $70.0 \mu \mathrm{l}$ of TEMED. After thorough mixing, the freshly prepared PAGEgel mix was poured into the space between plates and spacer. Then the comb wasinserted immediately with care so as to leave no air bubble inside the gel. Then the gel was allowed to polymerize at room temperature for $1 \mathrm{~h}$ and was given a pre-run at $150 \mathrm{~V}$ for 60 minutes in a vertical gel electrophoresis system. About $5 \mu \mathrm{l}$ of PCR product was taken in a $0.2 \mathrm{ml}$ PCR tube and $15 \mu \mathrm{l}$ denaturing formamide dye (Formamide, 95\%; Xylene cyanol, 0.025\%; Bromophenol blue, 0.025\%;0.5 M EDTA, 4\%) was added and mixed properly. The mixture of PCR product and formamide dye were denatured at $94^{\circ} \mathrm{C}$ for 5 minutes and snap chilled on ice for 5 minutes. The product was loaded immediately in gel carefully. The electrophoresis was performed at $4^{\circ} \mathrm{C}$ temperature at $150 \mathrm{~V}$ for 10 hours. After running, the gels were silver stained.

\section{Silver Staining}

For visualization of bands, silver staining was carried out as described by Sanguinetti (1994). The gel was kept in prestaining fixative solution (Pre-staining fixative Ethanol 10 $\mathrm{ml}$,Acetic acid $0.5 \mathrm{ml}$, Distilled water upto $100 \mathrm{ml}$ ) for 5 minutes and then the solution was discarded carefully. Then staining solution (Ethanol $10 \mathrm{ml}$, Acetic acid $0.5 \mathrm{ml}$, Silver nitrate $0.2 \mathrm{~g}$, Distilled water upto $100 \mathrm{ml}$ ) was added to the tank containing the gel and kept for $5 \mathrm{~min}$ in the dark. After discarding staining solution, the gel was washed with distilled water for 2 minutes. Then the developing solution (NaOH 3g, Formaldehyde $0.1 \mathrm{ml}$, Distilled water upto 100 $\mathrm{ml}$ ) was added to the tank and waited till the bands were properly developed(Fig. 5). Following staining, the gels were fixed further for 5 minutes in pre-staining fixative solution and washed in MilliQ water to have a permanent record of the experiment.

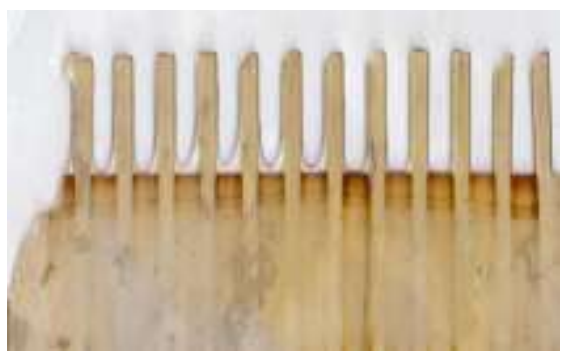

Fig. 5: PCR-SSCP genotypes of 311 bp fragment of CXCR1 gene

\section{DNA Sequencing}

The random two PCR products were purified using PCR purification kits (Fermentas) followed by custom sequencing (Fig. 6). The sequence obtained from different animals was subjected to BLAST analysis to ascertain that sequences were of CXCR1 gene.

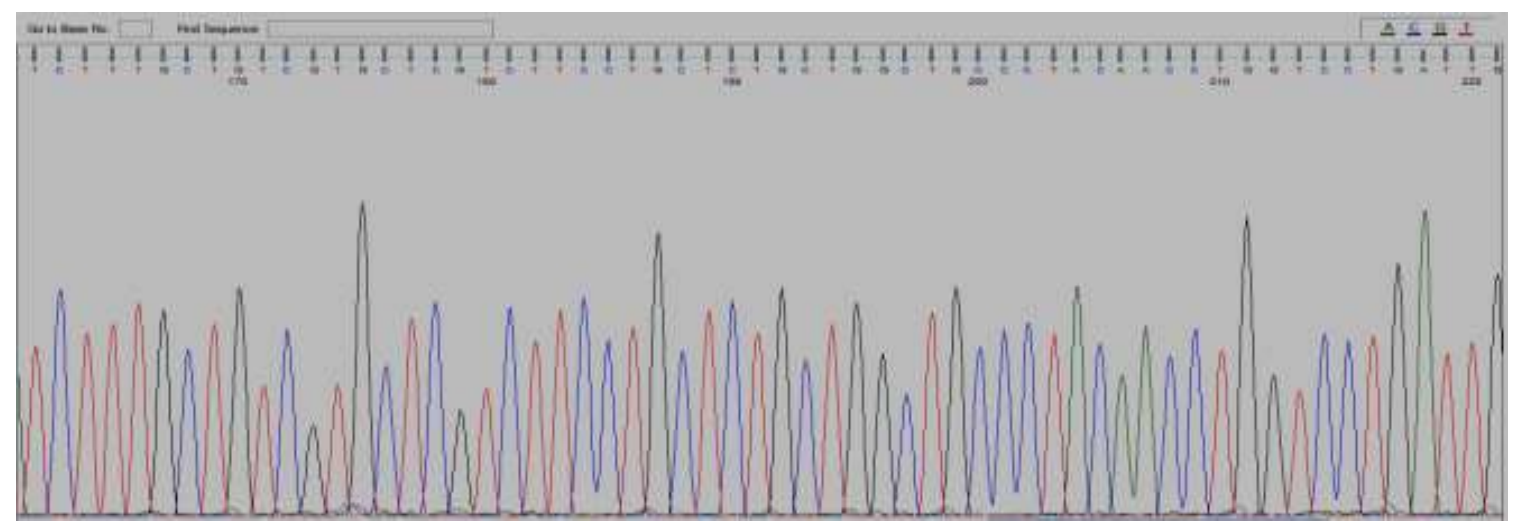

Fig. 6: DNA sequencing chromatogram 


\section{Results and Discussion}

A small 311 bp fragment of CXCR1 gene was amplified, followed by SSCP analysis. The SSCP analysis of $311 \mathrm{bp}$ fragment of CXCR1 gene revealed same patterns in all samples of buffaloes. Thus only one genotype was found for this fragment of CXCR1 gene. In other studies, SNPs association with mastitis has been reported only in case of cattle. But no report is available regarding SNP in buffalo yet. SNP (one) in the coding region (Youngerman et al. 2004) and one SNP in the 5' upstream region (Leyva-Baca et al., 2008) of CXCR1 were found to be associated with mastitis susceptibility in case of Holstein Cattle. Zhou et al. (2013) detected 4 single nucleotide polymorphisms (SNPs) of the CXCR1 gene in Chinese native cattle and found the significant association of c.337A $>\mathrm{G}$ and c.365C $>\mathrm{T}$ with the somatic cell score, which suggests the possible role of these SNPs in the host response against mastitis. In the present study, the reason for monomorphic pattern may be due to the partial segment taken for the study. Other regions of this gene including promoter need to be explored for the complete characterization of this gene. SNPs were detected in various studies on promoter region which were found to be associated with the mastitis tolerance/susceptibility.In case of cattle four SNPs, $-1830 \mathrm{~A}>\mathrm{G},-1768 \mathrm{~T}>\mathrm{A},-344 \mathrm{~T}>\mathrm{C}$, and $783 \mathrm{C}>\mathrm{A}$ were detected at 5'upstream and coding region, which were found to be associated with mastitis resistance in Chinese Holstein Cattle(Chen et al., 2011). Although we could not found any polymorphism in the coding region, but other factors related to farm management (education of the owner, type of labor and feeding after milking) were found to be significantly associated $(\mathrm{p}<0.05)$ with the occurrence of the disease. As various reports suggests that management factors could influence both infection pressure and host resistance resulting in a lower or higher mastitis prevalence and incidence (Piepers et al., 2011). Milking workers good hygiene was reported to be equally important for the disease control and it was found that cleaning the cubicles more frequently could reduce the exposure to environmental pathogens (Schukken et al.,1990).Poorly designed facilities could contribute to increased incidence of environmental mastitis. In all housing systems, high stocking density, dirty bedding or ground, infected utensils, poor ventilation and high humidity were important risk factors (Sudhan and Sharma, 2010). While looking on the animal associated determinants it has been found that increasing parity increased the risk of mastitis in buffaloes. Other reports were similar with the current findings (Kumar and Sharma, 2002; Sharma and Prasad 2002; Whist et al., 2006; Kavitha et al., 2009).

\section{Acknowledgement}

Financial assistance for conducting the research work provided by UGC and RKVY is highly acknowledged.

\section{References}

Ahuja SK, Murphy PM and Tiffany HL (1996) The CXC chemokines growth-regulated oncogene (GRO)-alpha, beta, -gamma, neutrophil activating peptide-2, and epithelial cell-derived neutrophil activating peptide-78 are potent agonists for the type $\mathrm{B}$, but not the type A, human interleukin-8 receptor. Journal of Biological Chemistry 271: 20545-550. DOI: $10.1074 /$ jbc.271.34.20545

Bansal BK and Gupta DK (2009) Economic analysis of bovine mastitis in India and Punjab-A review. Indian J. Dairy Sci. 67: 337-345

Burvenich C, Paape MJ, Hill AE , Guidry AJ, Miller, RH, Heyneman R, Kremer WD and Brand A (1994) Role of the neutrophil leucocyte in the local and systemic reactions during experimentallyinduced E. coli mastitis in cows immediately after calving Veterinary Questionnaire. 16: $45-50$.

Chen R, Yang Z,JiD, Ying YM, ZhangY, Hamza XW, Li Y (2011) SNPs of CXCR1 Gene and Its Associationswith Somatic Cell Score in Chinese Holstein Cattle. Animal Biotechnology 22(3): 133-142. DOI: 10.1080/10495398.2011.582804

Grosse WM, Kappes SM , Laegreid WW, Keele JW(1999) Single nucleotide polymorphism (SNP) discovery and linkage mapping of bovine cytokine genes. Mammalian Genome 10: $1062-1069$. DOI: $10.1007 / \mathrm{s} 003359901162$

Katritch V, Cherezov V, Stevens R C (2012) Diversity and modularity of $\mathrm{G}$ protein-coupled receptor structures. Trends Pharmacol. Sci. 33: 17-27. DOI: 10.1016/j.tips.2011.09.003

Kavitha K L, Rajesh K, Suresh K, Satheesh K, Syama Sundar N(2009) Buffalo mastitis - risk factors. Buffalo Bull 28(3): 134-137.

Kumar R. and Sharma A. 2002. Prevalence, etiology and antibiogram of mastitis in cows and buffaloes in Hisar, Haryana.Ind. J. Anim. Sci. 72: 361-63.

Lahaussa H, Pascal R, Alain C and Celine R (2008) Identification and characterization of a new interleukin- 8 receptor in bovine species. Molecular Immunology 45: 1153-1164. DOI: 10.1016/j.molimm.2007.07.011

Leyva-Baca I, Schenkel F, Martin J, Karrow N (2008) Polymorphisms in the 5' Upstream Region of the CXCR1 Chemokine Receptor Gene, and Their Association with Somatic Cell Score in Holstein Cattle in Canada. Journal of dairy science 91: 407-417. DOI: 10.3168/jds.2007-0142

Paape M J , Shafer-Weaver K , Capuco A V, Van Oostveldt K, Burvenich C(2000) Immune surveillance of mammary tissue by phagocytic cells. Advanced Experimental and Medical Biology 480: 259-277. DOI: 10.1007/0-30646832-8_31

Peveri P, Walz A, Dewald B and Baggiolini M (1988) A novel neutrophil-activating factor produced by human Polymorphonuclearleukocytes. Journal of Experimental Medicine 181: 1547-1559. DOI: 10.1084/jem.167.5.1547 
Piepers S, Peeters K, Opsomer G, Barkema HW, Frankena K and Vliegher SD (2011) Pathogen group specific risk factors at herd, heifer and quarter levels for intramammary infections in early lactating dairy heifers. Prev. Vet. Med. 99: 91-101. DOI: 10.1016/j.prevetmed.2011.02.010

Rainard P, Riollet C (2006) Innate immunity of the bovine mammary gland.Veterinary Research37: 369-400. DOI: 10.1051/vetres:2006007

Sambrook J and Russell DW (2012) Molecular cloning, a laboratory manual. Cold spring harbor laboratory press.NY,USA.

Sanguinetti C, Dias N E, Simpson A (1994) Rapid silver staining and recovery of PCR products separated on polyacrylamide gels. Biotechniques 17:914-21.

Schukken YH, Grommers FJ, Vandegeer D, Erb HN, B and A (1990) Risk factors for clinical mastitis in herds with a low bulk milk somatic cell count : Data and risk factors for all cases. J. Dairy Sci. 73: 3463-3471. DOI: 10.3168/jds.S0022-0302(90)79045-5
Sudhan N A and Sharma N (2010) Mastitis- An Important Production Disease of Dairy Animals.Farm management $\&$ diseases.Smvs“ dairy year book 2010.

Whist AC, Osteras O and Solverod L (2006) Clinical mastitis in Norwegian herds after a combined selective dry-cow therapy and teat-dipping trial. Journal of Dairy Science 74: 452-461. DOI: 10.3168/jds.s0022-0302(06)72515-2

Youngerman S, Saxton A, Oliver S and Pighetti G (2004) Association of CXCR2 polymorphisms with subclinical and clinical mastitis in dairy cattle. Journal of Dairy Science 87: 2442-2448. DOI: 10.3168/jds.S00220302(04)73367-6

Zhang C L,Fang X, Wang Y,GuC,Chen H(2012)The chemokine receptor 1 gene polymorphism and its association with Somatic Cell Score and milk production traits in dairy cattle.Animal Science Papers and Reports 30 (1): 25-33

Zhou L,Wang HM, Ju ZH, Zhang Y, Huang JM, Qi C, Hou MH, An LG, Zhong ZF and Wang CF (2013) Association of novel single nucleotidepolymorphisms of the $C X C R l$ gene with themilk performance traits of Chinese native cattle. Genetics and Molecular Research 12(3): 2725-2739. DOI: 10.4238/2013.July.30.10 